\title{
A IGREJA EPISCOPAL ANGLICANA E A QUESTÃO DA HOMOSSEXUALIDADE
}

\author{
Silvia Geruza Fernandes Rodrigues*
}

\begin{abstract}
RESUMO
Este trabalho tem como objetivo analisar os documentos das quatro mais recentes conferências de Lambeth (1978 a 2008), realizadas pela Igreja Episcopal Anglicana (doravante IEA), no que se refere à homossexualidade e seus desdobramentos. Refletir sobre a questão da homossexualidade trouxe grandes cismas dentro da IEA. Para dissertar a respeito dos documentos emitidos, recorreremos a clérigos da IEA, como o bispo britânico John Shelby Spong (2000), bispo Dom Robinson Cavalcanti $(1990,2011)$ e pastor Carlos Eduardo Calvani (2002). Os dois últimos, brasileiros, adotaram posições opostas em relação ao assunto. Apesar de toda a divisão e debates acirrados, parte da IEA progride em aceitar as descobertas científicas, o contexto, a cultura e uma nova hermenêutica das Escrituras ao lidar com a questão, acolhendo igualmente os membros na comunidade, independentemente da orientação sexual.

Palavras-chave: Homossexualidade. Anglicanismo. Igreja Episcopal Anglicana. Sexualidade.
\end{abstract}

\section{LA IGLESIA EPISCOPAL ANGLICANA Y LA CUESTIÓN DE LA HOMO- SEXUALIDAD}

\begin{abstract}
RESUMEN
Este trabajo tiene como objetivo analizar los documentos de las cuatro más recientes conferencias de Lambeth (1978 a 2008), realizadas por la Iglesia Episcopal Anglicana (IEA), en lo que se refiere a la homosexualidad y sus desdoblamientos. La reflexión sobre la cuestión
\end{abstract}

* Doutoranda em Ciências da Religião pela Pontifícia Universidade Católica de São Paulo (PUC-SP). Mestra em Ciências da Religião pela Universidade Metodista de São Paulo (UMESP). Especialista em Terapia Sistêmica Familiar e de Casal pela PUC-SP. Especialista em Sexualidade Humana pela FMUSP. 
de la homosexualidad trae grandes cismas dentro de la IEA. Para disertar sobre los documentos emitidos, recurriremos a clérigos de la IEA, como el obispo británico John Shelby Spong (2000), obispo monseñor Robinson Cavalcanti $(1990,2011)$ y pastor Carlos Eduardo Calvani (2002). Los dos últimos, brasileños, adoptaron posiciones opuestas en relación al asunto. A pesar de toda la división y debates intensos, parte de la IEA progresa en aceptar los descubrimientos científicos, el contexto, la cultura y una nueva hermenéutica de las Escrituras al tratar con la cuestión, acogiendo también a los miembros en la comunidad, independientemente de la orientación sexual. Palabras clave: Homosexualidad. Anglicanismo. Iglesia Episcopal Anglicana. La sexualidad.

\title{
THE ANGLICAN EPISCOPAL CHURCH AND THE ISSUE OF HOMOSE- XUALITY
}

\begin{abstract}
This article aims to analyze the documents from the last four Lambeth Conferences (1978 to 2008) held by the Episcopalian Anglican Church (from now on EAC) and their discussion on the subject of homosexuality, and their repercussion. In bringing about homosexuality in the Conferences has caused a great schism within the EAC. To analyze the documents, we will turn to some of their most important clergymen, such as the British Bishop John Shelby Spong (2000), Bishop Dom Robinson Cavalcanti (1990, 2011), and Pastor Carlos Eduardo Calvani. The last two are Brazilian with opposite points of view on the subject. Despite all the ruptures and long discordant debates, a part of the EAC progresses into accepting the scientific discoveries, the context, the culture and a new hermeneutic of the Scriptures in dealing with the subject, equally receiving persons independently of their sexual orientation, as members of the community.

Key-words: Homosexuality. Anglicanism. Human Sexuality. Anglican Episcopalian Church. Sexuality.
\end{abstract}

\section{INTRODUÇÃO}

O debate sobre a questão de gênero encontra-se efervescente na sociedade atual. Igrejas não conseguem colocar à margem o assunto da orientação sexual dos seus membros. Os fiéis homossexuais não mais 
se acomodam em caminhar excluídos dos processos eclesiásticos sem envolvimento nas diversas esferas das suas comunidades.

Se a sociedade tem sentido a urgência de debater a diversidade e as questões sobre a homossexualidade, as denominações cristãs não têm sido isentas da necessidade de debater o assunto e emitir documentos relatando sua visão a respeito do assunto, causando tensões, conflitos e divisões internas.

A Igreja Episcopal Anglicana (IEA) se debruçou sobre o assunto intensa e oficialmente, ao longo dos últimos 40 anos. Ela encontra o conflito entre a manutenção da tradição e ortodoxia institucional em seus postulados acerca da homossexualidade a partir da interpretação de alguns versículos bíblicos referentes ao assunto (Cf. Gn 19:5-7; Lev 18:22; Rm 1:21-27; 1 Cor 6:9-11) e a aquiescência à teologia crítica moderna que inclui a crítica hermenêutica, época e contexto. Segundo Fuchs (Tod SALZMAN; Michael LAWLER, 2012, p. 29), torna-se necessária uma nova abordagem tanto histórica como empírica da moralidade sexual, por envolver a ação humana que se desenvolve dinamicamente. Não se pode tomar dados do passado para apresentar um juízo moral no presente, sob o risco de se basear somente na interpretação da natureza.

Se tratar do assunto homossexualidade levanta cismas e dilemas, por que a IEA decidiu enfrentar o problema? A pressão da sociedade, dos fiéis gays e lésbicas de suas congregações, ou a urgência das novas descobertas científicas em relação à questão de gênero nos dois últimos séculos? O que a ciência traz à tona acerca da homossexualidade no século XXI? Seguir a tradição respeitaria as descobertas científicas sobre o ser humano e sua sexualidade?

Gaymond Bennett (2003) afirma que ciência e religião se inter-relacionam porque influenciam a vida, as preocupações e o "bem-estar de todas as pessoas e instituições ao redor do mundo" (Gaymond BENNETT 2003, p. 31). Para Bennett, seria inocência tentar isolar a ciência da religião com medo de que seja corrompida e a religião tentar se afastar da ciência com medo do secularismo. A ciência e a religião "permeiam a existência humana e se interpenetram" (p. 31). Se a religião, realmente se dispuser a sujeitar seus pressupostos à investigação científica do mundo natural, como propõe Bennett (Gaymond BENNETT, 2003, p. 
39), não entraria em contradição afirmar que respeita a "complexa realidade da pessoa humana" ao rejeitar a homossexualidade e chamá-la de "intrinsecamente desordenada"?

A questão da evolução biológica na ciência pode interferir na teologia? (William HEWLETT, 2003, p. 131). Em 1993, o cientista Deah H. Hamer e uma equipe de pesquisa no Instituto Nacional do Câncer nos Estados Unidos descobriram indícios de que a homossexualidade masculina - pelo menos parte dela - é genética. Segundo Hewlett (2003), os cientistas ainda não conseguiram encontrar a prova incontestável. Contudo, se realmente a homossexualidade for genética, levanta-se um problema ético, se considerarmos que a homossexualidade seja uma distorção da sexualidade "natural", como afirmam muitas denominações cristãs. Segundo Hewlett:

Para além da questão de culpa ou inocência, os eticistas antecipam outra questão: o risco do estigma. A presença do gene gay em um feto poderia ser considerada um defeito genético e fundamento para o aborto? Os testes genéticos de rotina levariam a uma redução geral de homens homossexuais de uma maneira paralela à redução de crianças com síndrome de Down? Isso seria considerado discriminação de classe? (William HEWLETT, p. 132).

Conforme Eduardo Cruz, "os avanços científicos contemporâneos (por exemplo, biologia evolutiva, neurociências, inteligência artificial etc.) são relevantes para um novo entendimento da pessoa humana" (Eduardo CRUZ, 2003, p. 223). A IEA se propôs nos seus documentos a se abrir para as novas descobertas científicas e médicas.

Na década de 60, emergiram novos descobrimentos científicos nas áreas de medicina, física e química, suscitando novos questionamentos existenciais, uma resistência a todo regime repressivo e um repúdio de normas congeladas de sexualidade e gênero (Lisa CAHILL, 1999).

Jovens começaram a contestar a ordem social: os costumes, a moral, a desigualdade de gênero. Movimentos feministas, inter-raciais, a liberação sexual, com críticas ao Estado, às grandes corporações, às instituições religiosas, principalmente as que se pretendiam regular as normas morais (Zuenir VENTURA, 1988). 
$\mathrm{Na}$ área científica, os relatórios Kinsey $(1948,1954),{ }^{1}$ e as pesquisas de William Masters e Virginia Johnson (1966), ${ }^{2}$ não somente se propuseram a responder a algumas perguntas ambíguas sobre sexualidade, como enfatizaram a "qualidade" da atividade sexual. John Gagnon (2006) considera a obra deles como motores propulsores da revolução sexual.

Após os relatórios Kinsey, segundo Gagnon, "qualquer tentativa de regular o comportamento sexual estava fadada ao fracasso" (John GAGNON, 2006, p. 16). Posicionamentos e conceitos religiosos cristalizados não mais comportariam os questionamentos dos membros de uma comunidade de fé.

A sociedade se achava efervescente com o advento da pílula anticoncepcional e casos de HIV/AIDS também emergindo dentro da própria IEA.

Esse artigo se propõe a analisar os quatro mais recentes documentos da Conferência de Lambeth, que são expedidos a cada dez anos, com suas decisões oficiais sobre assuntos debatidos, no nosso caso, a homossexualidade, a partir de 1978.

A cada dez anos bispos primazes, líderes da Igreja Episcopal Anglicana (IEA), com o arcebispo da Cantuária, reúnem-se em Lambeth, para discutir e escrever sobre tópicos considerados pertinentes à época, emitindo documentos com as resoluções que podem ser acolhidas ou não pelas igrejas da Comunhão Anglicana, respeitando a autonomia e a interdependência das regiões e paróquias.

1 Os relatórios fazem parte dos livros Sexual Behavior in the Human Male (1948) com Paul Gebhard e colaboradores e no Sexual Behavior in the Human Female. Somente o último livro foi publicado no Brasil sob o título A Conduta Sexual da Mulher, em 1954, pela editora Atheneu, e reeditado em 1967. Nele, há o relato e estatísticas de entrevistas pessoais com aproximadamente seis mil mulheres. Esses livros abalaram a comunidade puritana norte-americana e são passivos de muita crítica, mas que mudaram completamente as percepções sexuais na época e nos anos seguintes. Conferir artigo de Tito SENA sobre os relatórios, em http://www.fazendogenero. ufsc.br/g/resources/anais/1278011145_ARQUIVO_ArtigoTitoSenaFGg.pdf.

2 Os relatórios Masters \& Johnson, publicados em 1966 e 1970, sob os títulos respectivos A Resposta Sexual Humana e A inadequação Sexual Humana, foram produzidos nos Estados Unidos, a partir de uma minuciosa investigação científica das respostas fisiológicas e anatômicas da sexualidade masculina e feminina para tentar preencher as lacunas médicas, fisiológicas e psicológicas das estatísticas dos relatórios Kinsey $(1948,1953)$. Eles tiveram grande repercussão ao redor do mundo, não somente nos meios científicos e médicos, mas no comportamento e na qualidade de vida sexual dos seus leitores. 
O anglicanismo se entende como flexível teologicamente por permitir aos seus fiéis discordar "em assuntos não- essenciais" da sua fé descrita nos credos históricos. Ele se declara destituído de algum teólogo de vulto ou grande reformador e lança mão do que grandes homens e mulheres cristãos escreveram ao longo da história da igreja, sem necessariamente serem anglicanos. Utiliza-se do tripé: Escritura-Tradição-Razão, contanto que estejam em constante equilíbrio "a fim de discernir o que o Espírito Santo tem a dizer para a igreja".

Essa declaração permite a IEA abrir-se a novas ideias e conceitos sobre a sexualidade humana, exemplificados em documentos expedidos nas recentes conferências.

\section{CONFERÊNCIA DE LAMBETH (1978) - RESOLUÇÃO 10.3-RELACIO- NAMENTOS HUMANOS E SEXUALIDADE}

Nesse documento, a IEA ressalta a castidade dentro e fora do matrimônio, acolhimento aos divorciados e propostas de manter como sagrada a vida humana em relação ao aborto clínico e as implicações da engenharia genética.

Ele reafirma a heterossexualidade como a norma das Escrituras, porém reconhece a necessidade de um estudo profundo e desapaixonado da questão da homossexualidade, o que implica releitura das Escrituras e a aceitação dos resultados das pesquisas médicas e científicas.

Além de uma abertura à ciência, o documento encoraja diálogo com os homossexuais e ressalta que algumas igrejas membros da Comunhão Anglicana já refletem sobre o assunto.

Esse documento já foi o suficiente para alvoroçar bispos e clérigos da IEA em todo o mundo. Segundo Sidney Green (2013), a questão da homossexualidade levantou "debates raivosos que continuam até hoje e ameaçam a existência da Conferência de Lambeth e até mesmo a Comunhão Anglicana"3 (Sidney GREEN, 2013, p. 114. Tradução livre da autora).

A partir da declaração desse documento, concílios, reuniões de

A Comunhão Anglicana se compõe de quatro instrumentos: O arcebispo da Cantuária, As Conferências de Lambeth, A Conferência dos Primazes e o Concílio Consultivo Anglicano. 
primazes começaram a se organizar em todo o mundo, principalmente nos países da África, Ásia e América Latina para melhor compreenderem o assunto da homossexualidade e se prepararem para discuti-lo na próxima conferência.

Os países da África, Ásia e América Latina já se encontravam em ebulição quanto à aceitação de percepções "europeizadas" e em um movimento de descolonização. Isto é, bispos nativos começavam a se instalar e questionar a mensagem em uma vestimenta inglesa. Depois da Segunda Guerra Mundial, a IEA iniciou um movimento de afastar-se das lideranças impostas pela Europa e um processo de instalar seus próprios líderes nativos. Desde os anos 60, com a luta do Apartheid na África do Sul, a IEA começou um movimento histórico de cada vez mais ter suas próprias ideias e líderes nativos (Mark CHAPMAN, 2006).

$O$ assunto da homossexualidade constituiu-se mais um ponto distinto para acirrar a comoção de alguns questionamentos sociais e teológicos entre as igrejas da Comunhão Anglicana.

\subsection{CONFERÊNCIA DE LAMBETH (1988) - RESOLUÇÃO 64 - DIREITOS HUMANOS PARA AQUELES QUE TÊM ORIENTAÇÃO HOMOSSEXUAL}

Essa conferência:

1. Reafirma a declaração da Conferência de Lambeth de 1978 sobre homossexualidade, reconhecendo a necessidade na próxima década de "um estudo profundo e desapaixonado da questão da homossexualidade, que envolve seriamente tanto o estudo das Escrituras como os resultados de pesquisas científicas e médicas.

2. Tais estudos e reflexões urgem levar em conta as pesquisas biológica, genética e psicológica feitas por outras agências e os fatores socioculturais que levam a atitudes diferentes nas províncias da nossa Comunhão (Tradução da autora ). ${ }^{4}$

4 This conference: 1. Reaffirms the statement of the Lambeth Conference of 1978 on homosexuality, recognising the continuing need in the next decade for "deep and dispassionate study of the question of homosexuality, which would take seriously both the teaching of Scripture and the results of scientific and medical research". 2. Urges such study and reflection to take account of biological, genetic and psychological research being undertaken by other agencies, and the socio-cultural factors that lead to the different attitudes in the provinces of our Communion. 
Por causa do teor dessa conferência e da inquietação causada pela possibilidade de abordar a questão da homossexualidade, abriu-se exceção para que participassem todos os membros dos conselhos consultivos das igrejas anglicanas do mundo inteiro, como as igrejas de Bangladesh, Norte e Sul da Índia e Paquistão.

Essa conferência reafirma a resolução 1.0, de 1978, que considerou a abertura para estudar a questão da homossexualidade relacionada com o ensino das Escrituras e as mais novas descobertas das pesquisas científicas e médicas sobre o assunto.

Considera importante levar em conta as pesquisas biológica, genética e psicológica realizadas por outras áreas, e os fatores socioculturais que levam a diferentes atitudes nas províncias de Comunhão Anglicana. Vale ressaltar que em 73 províncias a homossexualidade ainda é criminalizada, e 13 preveem a pena de morte. ${ }^{5}$ Entre esses países, 38 se encontram na África e têm punições de 14 anos de prisão à prisão perpétua. Isso certamente pesou na discordância das decisões da Conferência de Lambeth em países asiáticos e africanos.

Portanto, não causa espanto, a recepção negativa aos relatórios expedidos pela Conferência de Lambeth quanto à abertura a novas descobertas médicas e científicas do relatório em 1988.

$\mathrm{Na}$ Conferência de 1988. aprovou-se a ordenação feminina ao ministério, ${ }^{6}$ que por sua vez também levantou fortes oposições. A argumentação considerou as Escrituras flexíveis devido à sua contextualização cultural, porém no caso da homossexualidade ponderou-se que a sociedade ainda se encontrava em dúvidas sobre a problemática. Tais considerações não permitiram à IEA avançar nos seus enunciados acerca das relações homoeróticas dos homossexuais.

\subsubsection{Conferência de Lambeth 1988 e seus desdobramentos}

Definitivamente, a sociedade e suas pressões influenciaram a abertura, ou a caminhada da IEA para debater a questão da homosse-

Conferir mais no artigo http://g1.globo.com/mundo/noticia/2016/06/relacao-homossexual-e-crime-em-73-paises-13-preveem-pena-de-morte.html. Acesso em 08/06/18.

6 A pressão para a ordenação da mulher ao ministério se fez notar com ordenações anteriores nas igrejas anglicanas dos Estados Unidos, Canadá e Nova Zelândia entre 1978 e 1984 (Sidney GREEN, 2013, p. 117). 
xualidade. Porém, setores conservadores questionaram mudanças em alguns dos seus preceitos ancorados na pressão da sociedade e não nas Escrituras. A divisão então ocorreu entre os chamados "conservadores" e os "liberalistas" ou "revisionistas".

A instalação da Conferência dos Primazes desde 1968 colaborou para várias reuniões em busca de restabelecer a doutrina anglicana firmada na tradição e nas Escrituras, principalmente no que concerne ao homossexual.

Em 1989, o bispo John Shelby Spong, de New Jersey, ordenou a diácono um gay que vivia com um parceiro. Em 1990, o bispo Walter Righter ordenou outro gay a diácono. A Convenção Geral dos Anglicanos nos Estados Unidos da América chamou os anglicanos a estudarem mais profundamente o assunto e os conclama a dialogar.

Em 1994, o bispo John Spong escreveu uma declaração denominada Koinonia Statement endereçada à Casa dos Bispos, declarando que tanto a homossexualidade como a heterossexualidade são moralmente neutras. Algumas de suas declarações caíram como uma bomba na IEA, tanto nos Estados Unidos como em outros países:

Cremos que o sexo é um dom de Deus. Cremos que alguns de nós somos criados heterossexuais e alguns de nós somos criados homossexuais. Cremos que a homossexualidade e a heterossexualidade são moralmente neutras, que ambas podem ser vividas com beleza, honra, santidade e integridade e que ambas são capazes de serem vividas destrutivamente também. Cremos que onde quer que seja que a sexualidade seja vivida destrutivamente esta igreja deve testemunhá-la negativamente. Nós nos opomos a todas as formas de sexo promíscuo, sexo que não honre o parceiro ou que não tenha seu parceiro em compromisso e amor. (...) Mas também cremos que os que são gays ou lésbicas que não querem viver sozinhos, mas se relacionarem com parceiros de sua escolha que sejam fiéis, monogâmicos, comprometidos, doadores da vida e santos devem ser honrados. Continuaremos a nos relacionar com esses casais com nosso apoio, nosso cuidado pastoral, nossas orações e nosso reconhecimento, de qualquer forma adequada de que Deus realmente está presente nas suas vidas juntos. ${ }^{7}$

Tradução livre da autora. Encontre a declaração na sua totalidade no link a seguir. <http:// www.integrityusa.org/archive/samesexblessings/a_statement in_koinonia.htm $>$. Acesso em 09/09/17. 
Essa declaração foi assinada por 90 bispos e 140 delegados da IEA. Contudo, bispos contrários a ela se reuniram para formar seus próprios grupos. Com isso, a IEA nos Estados Unidos experimentou três divisões e formou dois grandes segmentos: O grupo do Norte Global e do Sul Global. Em 1995, o bispo Halden, de Pittsburg, fundou o Conselho Americano Anglicano sob a alegação de que a cabeça da igreja estava doente e o medo de que estivessem afastando-se das suas raízes nas Escrituras. Ainda em 1995, Rev. Bill Atwood fundou a Sociedade Ekklesia para reunir anglicanos ortodoxos e vitalizar o movimento Sul Global. Os conservadores tanto do Norte como do Sul se fortaleceram a fim de atenderem em massa à Conferência de Lambeth, em 1998.

Em fevereiro de 1997, 80 delegados da IEA reuniram-se em Kuala Lumpur para discutir missões, unidade da igreja, mas principalmente acerca das suas decisões a respeito da homossexualidade. Na declaração sobre Escrituras, Família e a Sexualidade Humana, no parágrafo 6 reafirmaram que:

A Comunhão Anglicana deve voltar suas raízes em permanecer verdadeiros às Escrituras como sua autoridade máxima em todas as questões de fé e conduta; 2. As Escrituras veem o casamento como um relacionamento sagrado entre um homem e uma mulher, instituídos na ordenança da criação; 3. A única expressão, como ensinada pelas Escrituras, que honra a Deus e tem dignidade humana é entre um homem e uma mulher dentro da sagrada ordenança do casamento; 4. Acreditamos que as Escrituras sustentam que qualquer outra forma de expressão sexual é pecadora, egoísta, desonrosa a Deus e um abuso à dignidade humana; 5 . Estamos cientes dos efeitos danosos da promiscuidade sexual, incluindo a homossexualidade, o estupro e o abuso infantil dos nossos tempos. São problemas pastorais e chamamos nossas igrejas a encontrarem uma maneira bíblica e pastoral de trazer cura e restauração àqueles afetados por qualquer uma dessas tragédias angustiantes. ${ }^{8}$

8 Conferir a declaração no link <http://www.globalsouthanglican.org/index.php/blog/comments/ second_trumpet_from_2nd_anglican_encounter_in_the_south_kuala_lumpur_10_15.> Acesso em 09/09/17.

6. Scripture, the Family and Human Sexuality

Reflection on our Encounter theme has helped further deepen our resolve to uphold the authority of Scripture in every aspect life, including the family and human sexuality. Therefore: 
Pequenos grupos de bispos conservadores também se reuniram no Texas e em Kampala, Uganda, concentrando bispos da África Central e Oriental. Preocupados com a Igreja Episcopal Anglicana nos Estados Unidos, aprofundaram-se nas questões da Conferência de Lambeth, que supunham tomadas dentro da perspectiva Ocidental.

\subsection{Conferência de Lambeth (1998) - resolução 1.10 - sobre sexualidade humana}

Quanto à questão da homossexualidade no item d, o documento declara:

...ao mesmo tempo em que rejeita a prática homossexual como incompatível com as Escrituras, solicita a todas as pessoas que auxiliem, de maneira sensível e pastoral, todas as pessoas, independente de sua orientação sexual, escondem o medo irracional aos homossexuais, a violência no casamento e toda banalização e comercialização do sexo (Resolução 1.10, item d).

Essa conferência contou com a presença de 750 bispos, de 37 províncias. Devidamente preparados pelas reuniões anteriores a ela, os conservadores conseguiram que o documento reafirmasse rejeição à prática homossexual, posto que é vista como "incompatível com as Escrituras".

Esse documento reconhece que existem pessoas na igreja com orientação homossexual em busca de "cuidado pastoral” e se compromete a ouvir suas experiências, reafirmando-as como membros acolhidos

6.1 We call on the Anglican Communion as a Church claiming to be rooted in the Apostolic and Reformed Tradition to remain true to Scripture as the final authority in all matters of faith and conduct;

6.2 We affirm that Scripture upholds marriage as a sacred relationship between a man and a woman, instituted in the creation ordinance;

6.3 We reaffirm that the only sexual expression, as taught by Scripture, which honours God and upholds human dignity is that between a man and a woman within the sacred ordinance of marriage;

6.4 We further believe that Scripture maintains that any other form of sexual expression is at once sinful, selfish, dishonouring to God and an abuse of human dignity;

6.5 We are aware of the scourge of sexual promiscuity, including homosexuality, rape and child abuse in our time. These are pastoral problems, and we call on the Churches to seek to find a pastoral and scriptural way to bring healing and restoration to those who are affected by any of these harrowing tragedies. 
pela Igreja. Ressalta a condenação à homofobia, da mesma maneira que repreende a violência dentro do casamento e qualquer banalização e comercialização do sexo.

Ao mesmo tempo em que a declaração condena todo tipo de homofobia e expressa seu cuidado e acolhimento pela pessoa homossexual, ela confirma a rejeição à prática homossexual tida como "incompatível com as Escrituras".

Reafirma que não se pode aconselhar ou legitimar uniões do mesmo sexo nem ordenar gays e lésbicas ao ministério da igreja. Porém, solicita aos primazes e aos membros do Conselho Consultivo Anglicano a monitorarem trabalhos sobre o tema e a compartilhar declarações extraídas de suas Consultas. Contudo, encerra com um conceito ontológico que desfaz a dicotomia hetero/homo na igreja.

Nossas afeições sexuais não podem mais nos definir quem somos na nossa classe, raça ou nacionalidade. No mais profundo nível ontológico, portanto, não existe tal coisa como "um homossexual ou "um heterossexual"; por isso somos seres humanos, machos e fêmeas, chamados para redimir a humanidade em Cristo, cobertos com uma variedade complexa de potencialidades emocionais e ameaçados por uma complexa variedade de formas de alienação (Ponto 12). ${ }^{9}$

\subsection{Conferência de Lambeth (2008) - seção $\mathrm{h}$ - sexualidade humana}

$\mathrm{Na}$ tentativa de responder ao tumulto provocado pelas resoluções de 1998 sobre homossexualidade, essa conferência trata o assunto com mais clareza.

O documento chama a Comunhão Anglicana a se unir e respeitar as opiniões diferentes sobre a maneira de lidar com a questão da homossexualidade e a se conscientizar de que o fato de as igrejas se

9 Our sexual affections can no more define who we are than our class race or nationality. At the deepest ontological level, therefore, there is no such thing as "a" homosexual or "a" heterosexual; therefore, there are human beings, male and female, called to redeemed humanity in Christ, endowed with a complex variety of emotional potentialities and threatened by a complex variety of forms of alienation.

$\leq$ http://www.anglicancommunion.org/resources/document-library/lambeth-conference/1998/ section-i-called-to-full-humanity/section-i10-human-sexuality.aspx $\geq$ acesso em 04/06/2017. 
encontrarem em diferentes áreas, contextos sociais e experiências as leva a tomarem posturas e posicionamentos diferentes.

A resolução conclama ao arrependimento aqueles que por meio de suas declarações e atitudes feriram "a dignidade das pessoas homossexuais". Contudo, expressa que o casamento entre pessoas do mesmo sexo, ou a sua ordenação, tem trazido descontentamento e divisões na comunhão anglicana. ${ }^{10}$

O documento reafirma a abertura da Igreja Anglicana a continuar a discutir o assunto, que reconhece ser um assunto delicado porque entra em conflito com a longa tradição do ensino moral cristão. ${ }^{11}$

O ambiente tenso dentro da Comunhão Anglicana tornou-se notório no fato de que dos 800 bispos convocados, 200 se negaram a participar, principalmente do continente africano: Nigéria, Uganda, Quênia, Ruanda, e o bispo de Sidnei, Austrália. Em vez disso, mais de 1.100 bispos e clérigos anglicanos conservadores se reuniram em uma conferência sobre o Futuro Global do Anglicanismo (GAFCON) em Jerusalém. Sua missão, segundo eles, seria discutir dois grandes temas: a ordenação de mulheres e homossexuais. Peter Akinola da Nigéria, detentor do maior número de membros praticantes (cerca de 17,5 milhões), acreditava que o encontro seria de grande relevância para uma reforma na Comunhão Anglicana.

Essa reunião, obviamente, trouxe questionamentos sobre a autoridade do arcebispo de Cantuária, Rowan Williams, que propositalmente não havia convidado o bispo norte-americano gay, Gene Robinson, para a Conferência de 2008, para evitar maior fragilidade de uma Comunhão que já se encontrava dividida.

A GAFCON reafirmou a posição ortodoxa anglicana sobre a sexualidade humana, principalmente a homossexualidade com uma proposta de voltar às raízes de um “cristianismo autêntico”. Restabelece a criação

10 Nos Estados Unidos o bispo Gene Robinson foi ordenado bispo em New Hampshire e no Canadá têm sido realizados casamentos entre pessoas do mesmo sexo, o que tem causado divisões e provocado vários concílios e reuniões para discutir a questão. Até hoje, 2017, a Igreja Anglicana ainda não decidiu oficialmente para a Comunhão, a ordenação de homossexuais ao ministério nem o casamento entre pessoas do mesmo sexo.

1 Conferir o documento em sua totalidade em $\leq$ http://www.anglicancommunion.org/resources/document-library/lambeth-conference/2008/section-h-human-sexuality.aspx $\geq$ Acesso em $07 / 06 / 2017$. 
de Deus do homem e da mulher e reafirma o casamento heterossexual como norma.

Reconhecemos a criação por Deus da humanidade como macho e fêmea, e o padrão imutável do casamento cristão entre homem e mulher como o lugar apropriado para a intimidade sexual e a base da família. Arrependemo-nos por nossas falhas em manter esse padrão, e conclamamos uma renovação do compromisso de fidelidade duradoura no casamento e de abstinência para os em celibato (DECLARAÇÃO DE JERUSALÉM, 2008, p. 8).

Novamente, em 2013 o II GAFCON/FCA (Fraternidade de Anglicanos Confessantes) reuniu-se, desta vez em Nairóbi, África. Contou com a presença de 1.358 delegados: 331 bispos, 482 clérigos e 545 leigos representantes de 38 países. O tom da sua declaração não mostrou complacência aos documentos de Lambeth. Segundo a declaração, o GAFCON de 2008 foi um combate ao "falso evangelho":

...que estava se alastrando por toda Comunhão (...). Ele procurou mascarar condutas pecaminosas com a linguagem dos direitos humanos. Promoveu práticas homossexuais como sendo consistentes com a santidade, apesar do fato que a Bíblia identifica claramente como ato pecaminoso (COMUNICADO DE NAIROBI, 2013, ponto 1).

O documento de Nairóbi, então, reafirma o casamento heterossexual e se compromete a ser esse o seu ensino.

Comprometemo-nos a ensinar sobre o bom propósito de Deus para o casamento e para a vida solteira. O casamento é uma união para toda a vida exclusiva entre um homem e uma mulher. Encorajamos todas as pessoas a trabalhar e orar para a construção e fortalecimento de casamentos e famílias saudáveis. Por essa razão, somos contra a onda secular de ser a favor de coabitações e casamentos entre pessoas do mesmo sexo (COMPROMISSO DE NAIROBI, 2013, p. 1, ponto 6).

Jaci Maraschin (2017), presbítero da IEAB, responde à alegação de que estariam se utilizando de artifícios da pós-modernidade: 
Não sei bem se sabem o que estão dizendo. A pós modernidade não é uma agência nem um centro de poder. (...) É uma tendência à fragmentação que contraria o pensamento único, o autoritarismo e o dogmatismo (...). Para se classificar quem é ortodoxo é preciso que haja alguém infalível que faça a catalogação. Será que o bispo da Nigéria vai pedir ajuda à Cúria Romana, que entende melhor dessas coisas? ${ }^{12}$

Apesar das manifestações contra o conservadorismo, a Comunhão Anglicana permanece abalada diante da questão, e o arcebispo de Cantuária Rowan Williams foi tachado de arbitrário e sem autoridade diante das reuniões paralelas à Conferência de Lambeth.

\section{A IGREJA EPISCOPAL ANGLICANA BRASILEIRA E A QUESTÃO DA HOMOSSEXUALIDADE}

A IEA foi fundada no Brasil em 1890. Porém, somente em 1964 a Igreja Episcopal no Brasil ganha uma Província. Mais tarde, em 1965, mudaria seu nome para Igreja Episcopal Anglicana do Brasil. Em 1975, cria a primeira Diocese Setentrional, responsável pelo Norte e Nordeste do País.

Em 1997, o bispo Robinson Cavalcanti assume a diocese do Recife. Em dois dos seus livros: Uma bênção chamada sexo (1975) e Libertação e sexualidade (1992) Cavalcanti assume posições progressistas em relação à sexualidade, chegando a defender a poligamia, tema amplamente discutido, em 1998, na Conferência de Lambeth. Todavia, no exercício episcopal posiciona-se abertamente contra a aceitação da ordenação de pessoas homossexuais e casamento entre pessoas do mesmo sexo.

Em 2003, a ordenação do bispo Gene Robinson, assumidamente homossexual, pela diocese de New Hampshire, EUA, causou cisma na $I E A B$, encabeçada por Dom Robinson Cavalcanti que, insatisfeito com as declarações expedidas nas conferências de Lambeth, fincou sua posição de que a homossexualidade se constitui doença e transgressão às Escrituras, por isso passível de cura e arrependimento.

Em 2004, diante da comoção interna entre seus bispos e clérigos, a IEAB se reuniu para discutir a sexualidade humana, emitindo um

12 Simulacros e Simulações no Recife. Simulacrums and simulations in Recife. $<$ http://www.ieab. org.br/documentos/texto_maraschin.pdf >. Acesso em 10/09/17. 
documento que reafirmava o respeito à orientação sexual dos seus membros e chamando a IEAB a se unirem nesse propósito. ${ }^{13}$ Contudo, apesar dessa II consulta nacional sobre a sexualidade humana da IEAB, dom Robinson Cavalcanti continuou em sua jornada de não se submeter a resoluções não ortodoxas sobre a homossexualidade.

Em 2005, a IEAB destituiu Cavalcanti do seu cargo, porém ele permaneceu com a Diocese Anglicana do Recife, filiou-se à Fraternidade dos Anglicanos Confessantes (FCA) e à Igreja Anglicana da América do Norte, dissidentes da Igreja Episcopal Anglicana dos Estados Unidos, levando consigo 32 clérigos.

Ao sair da IEAB, Cavalcanti foi recebido pela Igreja Episcopal Anglicana do Cone Sul, sediada em Buenos Aires, e passaram a ter suas reuniões, independentes do arcebispo de Cantuária, Rowan Williams. Os grupos conservadores continuaram a se encontrar em Concílios e a emitir declarações em oposição à ordenação de pessoas homossexuais e casamentos entre pessoas do mesmo sexo.

Ao mesmo tempo, o pastor Carlos Eduardo Calvani (2002) se levantou como a voz defensora de decisões sobre a homossexualidade na IEAB. Em vários artigos, Calvani repele a postura fundamentalista de Dom Robinson Cavalcanti e aponta o maniqueísmo encontrado nos seus textos. ${ }^{14}$

Calvani (2002) levanta alguns pontos nos quais Robinson Cavalcanti se contradiz depois de passar a líder da Diocese Anglicana de Recife. Em alguns artigos ${ }^{15}$ Robinson Cavalcanti defende a ética "não como um conjunto de dogmas autoritariamente impostos" (Carlos Eduardo CALVANI, 2002, p. 18) e que a tradição "não tem instituição autoritativa que a interprete, mas deve ser entendida como a vivência, a experiência dos fiéis, histórica e universal”. Para Carlos Eduardo CALVANI, "a vivência é contextual, evitando-se, também, o privilegiar a experiência de uma época ou cultura, em detrimento de outras" (Carlos Eduardo CALVA-

13 Confira documento na íntegra no site <http://www.ieab.org.br/documentos/dec_2cssh.pdf. $>$ Acesso em 08/06/18.

14 Conferir texto no link <https://www.metodista.br/revistas/revistas-ims/index.php/COR/article/ view/1796/1781> artigo Deus e o diabo na terra do frevo. Calvani (2002). Acesso em 09/09/17.

15 Cavalcanti, Robinson. Enfrentando os desafios. Jornal Contexto Pastoral n. 19 (mar./abr. 1984), Suplemento Debate, p. 17-23. 
NI, 2002, p. 19). Contudo, segundo Calvani, parece que ao se referir à homossexualidade, Cavalcanti constantemente apela para a tradição.

Quantos aos princípios éticos, Calvani também chama a atenção para componentes em um livro de Cavalcanti, onde ele admite que cientistas e teólogos ainda encontram dificuldades em encontrar "possibilidades de reversão de opção". Porém, na carta "Entender e Decidir" ele propõe "a experiência de reversão de tendência (para a opção heteroerótica), atestada pelo testemunho de milhares de pessoas, pelo poder do mesmo Espírito" (In: Revista Eletrônica Correlatio n. 4 - dezembro de 2003, Deus e o diabo na terra do frevo. Carlos Eduardo CALVANI).

Em 2007, o bispo primaz da IEAB, Dom Mauricio José de Araújo de Andrade, assina o documento no qual declaram que a IEAB reafirma sua crença na inclusão, e que as reuniões que fomentam a divisão dentro da IEAB não partem de fundamentos teológicos, porque a própria estrutura da IEAB permite discordância de opiniões, advoga a tolerância e o diálogo entre as diversas vozes em seu meio. ${ }^{16}$

Contudo, o cisma ocorreu e, atualmente, $85 \%$ das Igrejas Episcopais Anglicanas no Brasil tornaram-se uma igreja independente que não deseja mais pertencer à Comunhão Anglicana e se uniram ao GAFCON, autodenominando-se ortodoxas e conservadoras, isto é, não aceitando que a homossexualidade possa ser aceita em seu meio como natural e que seus fiéis homossexuais não sejam celibatários ou busquem a "cura" para seu comportamento. Eles se reunirão em junho de 2018, em sua $3^{\text {a }}$, Conferência em Jerusalém, esperando reunir três mil anglicanos de todo o mundo.

\section{ANÁLISE E DISCUSSÕES}

O tema da homossexualidade tornou-se mais acirrado dentro da IEA a partir de 1978, com a resolução 1.10. Essa declaração contém, em sua conclusão, um avanço notório sobre a questão da homossexualidade, ao mesmo tempo em que reconhece outras opiniões em outras conferências anglicanas ao redor do mundo.

16 Confira a declaração em sua íntegra no site <http://www.ieab.org.br/ documentos/c_past_sex_07.pdf $>$. Acesso em 08/06/18. 
Em fevereiro de 1997, mais de 80 delegados de Igrejas Anglicanas de dois terços do mundo se reuniram para o Segundo Encontro Anglicano no Sul, em Kuala Lumpur, Malásia. Dessa reunião, resultou uma declaração reafirmando a criação do homem e da mulher (Gn 3) e que somente aceitavam o matrimônio entre homem e mulher, e que as igrejas que realizarem casamento entre pessoas do mesmo sexo questionam a autoridade das Escrituras. Portanto, pessoas que sentem atração por outras do mesmo sexo são encorajadas a procurar ajuda pastoral para cura, correção e arrependimento.

A Conferência de Lambeth, 1998, Resolução I.10 sobre a sexualidade humana, reporta que a seção da América Latina, tomou igual resolução de reforçar "os valores da família cristã, e a reafirmou a ética sexual “tradicional” dos anglicanos" (Resolução V. 10 da Região da América Latina). ${ }^{17}$

Na resolução V. 23 da Região Sudeste da Ásia, Kuala Lumpur, também na Conferência de Lambeth 1998, Resolução I.10 sobre a sexualidade humana, a declaração encerra afirmando que "a homossexualidade é um pecado que só poderia ser adotada pela igreja que quisesse cometer um suicídio evangélico" (Resolução V. 23).

Em 2006, o arcebispo de Cantuária, Dr. Rowan Williams, necessitou emitir um documento analisando a situação conflitante na qual se encontrava a IEA, devido à decisão dos Estados Unidos de ordenar gays e lésbicas ao bispado, e do Canadá de realizar uniões com casais do mesmo sexo, em 2003.

No elã de unir as IEAS, Rowan WILLIAMS (2006) estabelece a diferença entre sua instituição e a Igreja Católica Romana, ${ }^{18}$ que se constitui em uma igreja com hierarquia única, enquanto a IEA se compõe de uma comunidade, onde cada igreja local de acordo com sua cultura e contexto recebe as diretrizes e as avalia. Ele conclama a Comunhão Anglicana a estudar e tentar se utilizar de melhores métodos de per-

17 Conferir documento completo em <http://www.anglicancommunion.org/media/76650/1998. pdf>. Acesso em 08/06/18.

18 Vale ressaltar que até seu último documento oficial, em 2005, o Compêndio do Catecismo da Igreja Católica, a Igreja Católica Romana continua a considerar a homossexualidade como perversão, reafirmando a "lei natural" - a complementaridade homem e mulher e o ato conjugal somente permitido no matrimônio heterossexual e monogâmico, com abertura à procriação. 
manecer unidos ao redor dos assuntos discutidos e suas resoluções. Veladamente, condena as igrejas nos Estados Unidos e no Canadá por tomarem condutas isoladamente opostas às diretrizes das conferências anteriores, em relação à ordenação de gays e lésbicas e realizar casamentos entre pessoas do mesmo sexo.

A IEAB, por sua vez, exclui o dissidente Dom bispo Robinson Cavalcanti de sua instituição, que saiu com a Diocese Anglicana de Recife, com 32 clérigos e se uniu ao Cone Sul, formando um grupo maior de conservadores e "ortodoxos" anglicanos, que se opuseram ao arcebispo de Cantuária e aos documentos expedidos pelas conferências de Lambeth.

O GAFCON/FCA constituem-se movimentos conservadores que crescem com toda a sua força financeira, política e aglutinadora, ameaçando assim a Comunhão Anglicana.

Como resultado, o atual arcebispo de Cantuária, John Welby adiou a Conferência de Lambeth que aconteceria em 2018, até visitar as províncias e tentar um diálogo para que a maioria compareça em 2020, possivelmente.

\section{CONSIDERAÇÕES FINAIS}

A Igreja Episcopal Anglicana enfrentou o assunto da homossexualidade debaixo de muita tensão, cuidado e conflitos.

O fato da IEA não possuir um personagem central e sim uma comunhão de igrejas onde seus clérigos desfrutam da liberdade de concordar ou discordar das resoluções tomadas em suas conferências, provavelmente tem facilitado o avanço no debate e nas conclusões sobre o acolhimento e a aceitação da pessoa homossexual como capaz de ser integrada na comunidade, sem o estigma de "patologia". Em inúmeras regiões, a IEA conseguiu avançar no debate, onde não se considera mais a homossexualidade como patológica ou um comportamento desviante.

Todavia, as diretrizes dos documentos oficiais das Conferências de Lambeth não encontraram uma aceitação unânime entre seus bispos e teólogos, que se movimentaram para discutir e contra-argumentar conceitos estabelecidos sobre a homossexualidade.

Muitos teólogos anglicanos se levantaram contra a decisão de aceitar a inclusão dos homossexuais por considerá-la contrária ao en- 
sino tradicional das Escrituras. Devido à autonomia entre as igrejas nas diversas regiões onde se encontra estabelecida, a IEA se constitui uma denominação religiosa flexível e aberta ao diálogo com a questão da homossexualidade.

Nesses últimos 40 anos, observam-se avanços e recuos na IEA, porém com um renovado esforço de acolher os homossexuais e aceitá-los como membros da igreja de Cristo.

Por trazer a questão da homossexualidade à tona, a IEA experimentou conflito e divisões entre as igrejas. Contudo, torna-se necessário enfrentar tal assunto, da mesma maneira que se confrontou a escravidão, a inclusão da mulher, justiça social e os direitos humanos. Permitir que o passado ensine como atuar no presente para evitar arrependimentos futuros consiste na base do fluir das instituições religiosas.

Apesar dos recuos e das perdas, a IEA ainda é, dentro do mundo religioso, uma instituição que se abre para o diálogo com a sociedade, a ciência e se dispõe a revisar seus posicionamentos dogmáticos de séculos passados.

\section{REFERÊNCIAS}

A CONFERÊNCIA DE LAMBETH - 1978. <http://www.anglicancommunion.org/resources/ document-library/lambeth-conference/1978/resolution-10-human-relationships-and-sexu ality?author=Lambeth+Conference\&year $=1978>$. Acesso em 10/09/17.

A CONFERÊNCIA DE LAMBETH - 1988. <http://www.anglicancommunion.org/resources/ document-library/lambeth-conference/1988/resolution-34-marriage-and-family.aspx >. Acesso em 10/09/17.

A CONFERÊNCIA DE LAMBETH - 1998. http://www.anglicancommunion.org/resources/ document-library/lambeth-conference/1998/section-i-called-to-full-humanity/section-i10-human-sexuality.aspx. Acesso em 04/06/2017.

A CONFERÊNCIA DE LAMBETH - 2008. http://www.anglicancommunion.org/resources/ document-library/lambeth-conference/2008/section-h-human-sexuality.aspx. Acesso em 07/06/2017.

A DECLARAÇÃO DE JERUSALÉM. <http://www.igrejaanglicana.net/2008/06/a-declaracao-de-jerusalem.html>. Acesso em 09/09/17.

BATES, Stephen. A church at war: Anglicans and homosexuality. London: I.B. Taurus \& Co. Ltd, 2004. 
CALVANI, Carlos Eduardo. Deus e o diabo na terra do frevo, $2002<$ https://www.metodista.br/revistas/revistas-ims/index.php/COR/article/view/1796/1781> Acesso em 09/09/17. . Deus e o diabo na terra do frevo. Revista Eletrônica Correlatio, n. 4, dez. 2003. Acesso em 09/09/17.

CAVALCANTI, Robinson. Enfrentando os desafios. Jornal Contexto Pastoral, n. 19 (mar./ abr. 1984), Suplemento Debate, p. 17-23.

CHAPMAN, Mark. Anglicanism: A very short introduction. Oxford: Oxford University Press, 2006.

GAGNON, John. H. Uma interpretação do desejo. Ensaios sobre o estudo da sexualidade. Rio de Janeiro: Garamond, 2006.

GREEN, Sidney L. Beating the bounds - A symphonic approach to orthodoxy in the Anglican Communion. Eugene, Oregon: Wipf\&Stock, 2013.

HALL, Caroline J. Addington. A thorn in the flesh - How gay sexuality is changing the Episcopal Church. Plymouth UK: Rowman \& Littlefield Publishers, 2013.

HEWLETT, William. In: PETERS, Ted; BENNETT Gaymon (Orgs.). Construindo pontes entre a ciência e a religião. São Paulo: Edição Loyola; Editora UNESP, 2003, p. 113.

MARASCHIN, Jaci. Simulacros e Simulações no Recife. Simulacrums and simulations in Recife. <http://www.ieab.org.br/documentos/texto_maraschin.pdf>. Acesso em 10/09/17.

O COMUNICADO DE NAIROBI. <http://www.igrejaanglicana.net/2013/10/gafcon-2013-comunicado-de-nairobi.html> Acesso em 09/09/17.

PETERS, Ted; BENNETT Gaymon (Orgs.). Construindo pontes entre a ciência e a religião. São Paulo: Edição Loyola; Editora UNESP, 2003.

SACHS, William L. Homosexuality and the crisis of Anglicanism. Cambridge University Press: New York, 2009.

SALZMAN, Tod e LAWLER, Michael G. A pessoal sexual - Por uma antropologia católica renovada. São Leopoldo, RS: Editora Unisinos, 2012.

SENA, Tito. Os relatórios Kinsey: práticas sexuais, estatísticas e processos de normali(ti) zação. Disponível em http://www.fazendogenero.ufsc.br/9/resources/anais/1278011145_ ARQUIVO_ArtigoTitoSenaFG9.pdf Acesso em 08/06/18.

SPONG, John. Koinonia Statement. <http://www.integrityusa.org/archive/ samesexblessings/a_statement_in_koinonia.htm>. Acesso em 09/09/17.

VENTURA, Zuenir. 1968, 0 ano que não terminou, 13 ed. Rio de Janeiro: Editora Nova Fronteira, 1988.

Submetido em: 25-4-2018

Aceito em: 10-6-2018

Mandrágora, v.24. n. 1, 2018, p. 141-161 